\title{
Stimulation of non-specific immunity, gene expression, and disease resistance in Nile Tilapia, Oreochromis niloticus (Linnaeus, 1758), by the methanolic extract of the marine macroalga, Caulerpa scalpelliformis
}

\author{
Omita Yengkhom\#, Konda Subramanian Shalini\#, P. A. Subramani and R. Dinakaran Michael \\ Centre for Fish Immunology, Vels Institute of Science, Technology and Advanced Studies (VISTAS), Chennai, Tamil \\ Nadu, India. \\ Corresponding author: R. Dinakaran Michael, e-mail: dean.sls@velsuniv.ac.in \\ Co-authors: OY: omita@velsuniv.org, KSS: shalini86.s@gmail.com, PAS: parasuraman.sls@velsuniv.ac.in \\ \#Equally contributed \\ Received: 15-11-2018, Accepted: 11-01-2019, Published online: 16-02-2019
}

doi: 10.14202/vetworld.2019.271-276 How to cite this article: Yengkhom O, Shalini KS, Subramani PA, Michael RD (2019) Stimulation of non-specific immunity, gene expression, and disease resistance in Nile Tilapia, Oreochromis niloticus (Linnaeus, 1758), by the methanolic extract of the marine macroalga, Caulerpa scalpelliformis, Veterinary World, 12(2): 271-276.

\begin{abstract}
Aim: The objective of the present study was to test the immunostimulating potential of marine macroalga, Caulerpa scalpelliformis, in terms of non-specific immune responses, gene expression, and disease resistance of Nile tilapia, Oreochromis niloticus (Linnaeus, 1758).

Materials and Methods: $O$. niloticus was injected intraperitoneally with three different doses of methanol extract of C. scalpelliformis (CSME) $\left(2 \mathrm{mg} / \mathrm{kg}, 20 \mathrm{mg} / \mathrm{kg}\right.$, or $200 \mathrm{mg} / \mathrm{kg}$ body weight), or MacroGard ${ }^{\mathrm{TM}}$ (commercial immunostimulant, positive control, and $20 \mathrm{mg} / \mathrm{kg}$ body weight), or distilled water (untreated control). In one set of fish, 5 days post-injection, serum lysozyme, myeloperoxidase, and antiprotease activities were assayed. $24 \mathrm{~h}$ after injection, gene expression was analyzed in a separate set of fish. To another set of fish, 1 week post-administration of the products, fish were challenged with lethal dose $50\left(\mathrm{LD}_{50}\right)$ dose of a live virulent pathogen, Aeromonas hydrophila and subsequent resistance to it was noted in terms of cumulative percent mortality.
\end{abstract}

Results: CSME increased serum lysozyme, myeloperoxidase, and antiprotease activities. There was an increase in the expression of lysozyme gene in the spleen of treated fish. Mid dose of CSME caused the minimum mortality of $10 \%$ (consequent relative percentage survival $=73$ ) which is comparable to that of the positive control.

Conclusion: CSME is considered to have the potential to be developed into an immunostimulant for finfish aquaculture.

Keywords: Aeromonas hydrophila, Caulerpa scalpelliformis, immunostimulant, macroalga, Oreochromis niloticus.

\section{Introduction}

Fish are an excellent source of many vital nutrients including proteins, vitamins, and minerals required for the human body. Amount of fishes captured from oceans, seas, and rivers are diminishing rapidly. On the other hand, global aquaculture is expanding swiftly [1]. However, the substandard practices involved in fish rearing resulted in a range of fish diseases. Some of the disease treatment methods such as the use of antibiotics or vaccines cannot be successfully employed due to their limitations reviewed elsewhere [2]. Hence, the use of immunostimulants as a prophylactic measure for disease treatment is gaining much interest $[3,4]$.

Macroalgae have various compounds with varied biological activities [5]. Caulerpa scalpelliformis belonging to Caulerpaceae family of macroalgae is

Copyright: Yengkhom, et al. Open Access. This article is distributed under the terms of the Creative Commons Attribution 4.0 International License (http://creativecommons.org/licenses/ by/4.0/), which permits unrestricted use, distribution, and reproduction in any medium, provided you give appropriate credit to the original author(s) and the source, provide a link to the Creative Commons license, and indicate if changes were made. The Creative Commons Public Domain Dedication waiver (http:// creativecommons.org/publicdomain/zero/1.0/) applies to the data made available in this article, unless otherwise stated. one of the common seaweeds, found along the coast in many regions of the world. Caulerpa species have been shown to have antidiabetic [6], anti-inflammatory [7], antioxidant [8], and anti-proliferative [9] activities. Nile tilapia, Oreochromis niloticus also named as "Food fish of the $21^{\text {st }}$ century" [10] is robust fish which can dwell well even in hostile aquatic environments. O. niloticus is the second most reared fish after carps [11]. Aeromonas hydrophila is one of the most prevalent pathogens responsible for serious fish diseases such as motile aeromonad septicemia [12]. Hence, it is imperative to find out potential immunostimulants to fight against the onslaught of pathogens.

This study reports the modulation of non-specific immunity, expression of immune genes and protection from $A$. hydrophila infection in fish after an intraperitoneal administration of methanolic extract of C. scalpelliformis (CSME).

\section{Materials and Methods}

\section{Ethical approval}

The International Ethical Committee's recommendation on "Guidelines for the use of fish in research" [13] was followed while handling the fish. 
Fish

All male-Nile tilapia ( $\mathrm{n}=300)$, weighing $45 \pm 5 \mathrm{~g}$ were procured from Svara Biotechnovations, Madurai, India $\left(10^{\circ} 09^{\prime \prime} \mathrm{N}, 78^{\circ} 19^{\prime} \mathrm{E}\right)$. After acclimation to laboratory conditions for 2 weeks, experiments were conducted. All the experiments were conducted in $150 \mathrm{~L}$ fiber reinforced plastic tanks fitted with external re-circulating biofilters (Eheim, Deizisau, Germany). Fish were kept in ambient light and temperature $\left(27 \pm 2^{\circ} \mathrm{C}\right)$ conditions throughout the experiments. Water quality parameters such as total dissolved solids, $\mathrm{pH}$, and dissolved oxygen were maintained within permissible limits for Nile tilapia $[11,14]$. Ammonia and nitrate levels were minimized by the bacteria present in the biofilters.

\section{Preparation of methanol extract}

The method of Das et al. [15] was followed for preparing CSME. Briefly, air-dried macroalgal material (150 g) was immersed in $2.5 \mathrm{~L}$ methanol and incubated at $15^{\circ} \mathrm{C}$ for 7 days with intermittent stirring. The resultant extract was filtered using a sterile muslin cloth, concentrated using a rotary vacuum evaporator (Buchi, Switzerland) and air dried to a pasty consistency. The dried extract was stored at $-20^{\circ} \mathrm{C}$ till used for experiments.

\section{Experimental design}

All the experiments were conducted according to our earlier procedures [14]. Each experiment consisted of five groups in triplicate tanks (total number of tanks = 15). To one group of fish, distilled water was injected that functioned as an untreated control group. The next three groups of fish were administered with three different doses of methanol extract 2 , 20 , or $200 \mathrm{mg} / \mathrm{kg}$ (body weight of fish). The last group was injected with $20 \mathrm{mg} / \mathrm{kg}$ MacroGard ${ }^{\mathrm{TM}}$ (Biotech Pharmacon ASA, Tromso, Norway) which is a commercially available immunostimulant and acted as a positive control.

\section{Serum non-specific immune assays}

For assessing the non-specific immune mechanisms, six fish per group (treatments of different groups given above) were maintained in triplicate tanks and four fish from each tank were used (a total of 12 fish/ group for each assay). Fish were first anesthetized in 100 ppm of 2-phenoxyethanol (HiMedia, Mumbai, India) followed by drawing $0.2 \mathrm{~mL}$ blood from the common cardinal vein [16] using a tuberculin syringe fitted with a 24 gauge needle. The collected blood in serological tubes was kept for $1 \mathrm{~h}$ at room temperature and further overnight at $4^{\circ} \mathrm{C}$ for separation of serum. Serum was then separated by spinning the serological tubes the next day for $10 \mathrm{~min}$ at $400 \times \mathrm{g}$. The serum obtained was stored at $-20^{\circ} \mathrm{C}$ until used for the assays.

Serum lysozyme assay was done according to the method described earlier by Hutchinson and Manning [17] with Micrococcus lysodeikticus (SigmaAldrich, USA) as the substrate. The optical density (OD) was determined at $490 \mathrm{~nm}$ with a microplate reader (Bio-Rad, Hercules, USA). Reduction of OD by 0.001 absorbance unit per minute was defined as one unit of lysozyme activity [17].

Serum myeloperoxidase activity was measured using the protocol of Quade and Roth [18]. Briefly, sera were diluted 10-fold using phenol red-free Hank's balanced salt solution having $\mathrm{Mg}^{2+}$ and EGTA. To the diluted sera, $50 \mu \mathrm{L}$ tetramethylbenzidine-hydrogen peroxide $\left(\mathrm{H}_{2} \mathrm{O}_{2}\right)$ (Genei, Bengaluru, India) was added and incubated for $2 \mathrm{~min}$ at room temperature for the color development. The color development reaction was abruptly stopped by the adding $50 \mu \mathrm{L} 2 \mathrm{M} \mathrm{H}_{2} \mathrm{SO}_{4}$. The OD of the samples versus $100 \mu \mathrm{L}$ of HBSS as blank was noted at $450 \mathrm{~nm}$.

The method of Bowden et al. [19] was used to measure the percentage inhibition of trypsin (serum antiprotease) activity. Serum $(10 \mu \mathrm{L})$ was incubated with $0.1 \%$ trypsin $(20 \mu \mathrm{L})$ (HiMedia, Mumbai, India) prepared in $0.01 \mathrm{M}$ Tris- $\mathrm{HCl}$ buffer, $\mathrm{pH} 8.2$ for $5 \mathrm{~min}$ in serological tubes. The incubation was followed by the addition of $500 \mu \mathrm{L}$ of sodium-benzoyl-DL-arginine-p-nitroanilide (BAPNA, SRL chemicals, Chennai, India) and $470 \mu \mathrm{L}$ of buffer. Trypsin incubated with BAPNA alone was considered as trypsin blank for calculation. The incubation was continued for another $25 \mathrm{~min}$ at $22^{\circ} \mathrm{C}$. Finally, the reaction was terminated by the addition of $30 \%$ acetic acid $(150 \mu \mathrm{L})$. OD was measured at $415 \mathrm{~nm}$ by taking $200 \mu \mathrm{L}$ of this reaction mixture against Tris- $\mathrm{HCl}$ buffer as blank. Percentage inhibition of trypsin activity was then calculated using the formula [14]:

$$
\begin{gathered}
\text { Percentage trypsin } \\
\text { inhibition }
\end{gathered}=\frac{\text { Trypsin blank OD }- \text { Sample OD }}{\text { Trypsin blank OD }} \times 100
$$

\section{Modulation of immune genes expression}

For studying the expression of immune-associated genes, three fish per group (total 15 numbers) were distributed to five groups as mentioned above, and respective CSME products were intraperitoneally administered to the fish in each group. After $24 \mathrm{~h}$ of administration, fish were sacrificed by an overdose of 2-phenoxyethanol for the collection of the spleen. Collected spleens were preserved in RNAlater (Sigma-Aldrich, St. Louis, USA) and stored at $-20^{\circ} \mathrm{C}$ until extraction of RNA was carried out. Gene expression analysis was then conducted according to our earlier protocols [14].

Total RNA was extracted using Trizol (Sigma, Bengaluru, India) following the manufacturer's protocol. Subsequently, RNA extraction was followed by the synthesis of cDNA in a thermocycler (Eppendorf Mastercycler ${ }^{\circledR}$ Nexus, Hamburg, Germany) with the use of Omniscript Reverse Transcription Kit (Qiagen, Bengaluru, India). To perform the gene expression analysis of lysozyme, $\beta$-actin was used as a housekeeping gene. REDTaq ${ }^{\circledR}$ Readymix polymerase chain reaction (PCR) reaction (Sigma, Bengaluru, India) and nuclease-free water (Sigma, Bengaluru, India) including forward and reverse primers were used for the PCR reaction. The primer sequence and 
conditions for reactions are given in Table-1 $[20,21]$. Electrophoresis of the PCR products was performed in $1.5 \%$ agarose gel which included $10 \mu \mathrm{g} / \mathrm{mL}$ ethidium bromide (Medox, Chennai, India). Electrophoresed gel was then viewed in a gel documentation system (Proteinsimple, New Delhi, India) and photographed. The PCR product quantification was done with Image J $\mathrm{v} 1.50 \mathrm{~b}$ software for windows [22] using the photograph obtained from the gel documentation system.

\section{Challenge to fish}

Fish in the five different groups (10 fish/group in triplicates) as mentioned above were injected intraperitoneally with various doses of CSME, MacroGard ${ }^{\mathrm{TM}}$ or sterile distilled water. 1 week post-injection, fish in all the five groups were challenged with lethal dose $50\left(\mathrm{LD}_{50}\right)$ of $A$. hydrophila. Cumulative mortality for a period of 15 days was noted and used for calculating the percent mortality. A. hydrophila was reisolated from the tissues of dead fish using Rimler-Shott's medium (HiMedia, Mumbai, India) to confirm the death of the fish was due to $A$. hydrophila. Relative percent survival was then calculated from percentage mortality using the formula used in our previous studies [14]:

$$
\text { RPS }=\frac{1-\text { Percent mortality in treated group }}{\text { Percent mortality in control group }} \times 100
$$

\section{Statistical analysis}

Statistical analysis was done with the use of Sigmaplot v.11. Data were expressed as mean \pm standard error and analyzed by one-way ANOVA followed by Tukey's a posteriori test with a significance level of $\mathrm{p}<0.05$.

\section{Results}

The low dose of CSME boosted the serum lysozyme activity which was significantly $(\mathrm{p}<0.05)$ different from that of the untreated control. MacroGard ${ }^{\mathrm{TM}}$ also significantly increased lysozyme activity (Figure-1a). Enhancement in serum myeloperoxidase by a low dose of CSME was significantly $(p<0.05)$ different from that of the untreated control and its effect was indifferent to that of MacroGard ${ }^{\mathrm{TM}}$ (Figure-1b). In serum antiprotease activity, the low and mid doses of CSME significantly $(p<0.05)$ enhanced the percent trypsin inhibition comparable to that of the positive control, MacroGard ${ }^{\mathrm{TM}}$ (Figure-1c).

The low and high doses of CSME caused significant $(p<0.05)$ upregulation of lysozyme gene expression though positive control did not show any enhancement (Figure-2). The mid and high doses of CSME and positive control significantly reduced the percent mortality of fish infected with $A$. hydrophila. As shown in Figure-3, the mid dose and MacroGard ${ }^{\mathrm{TM}}$ showed the lowest percentage mortality (10\%).

\section{Discussion}

There is an urgent requirement for alternatives to vaccines and antibiotics for disease control in
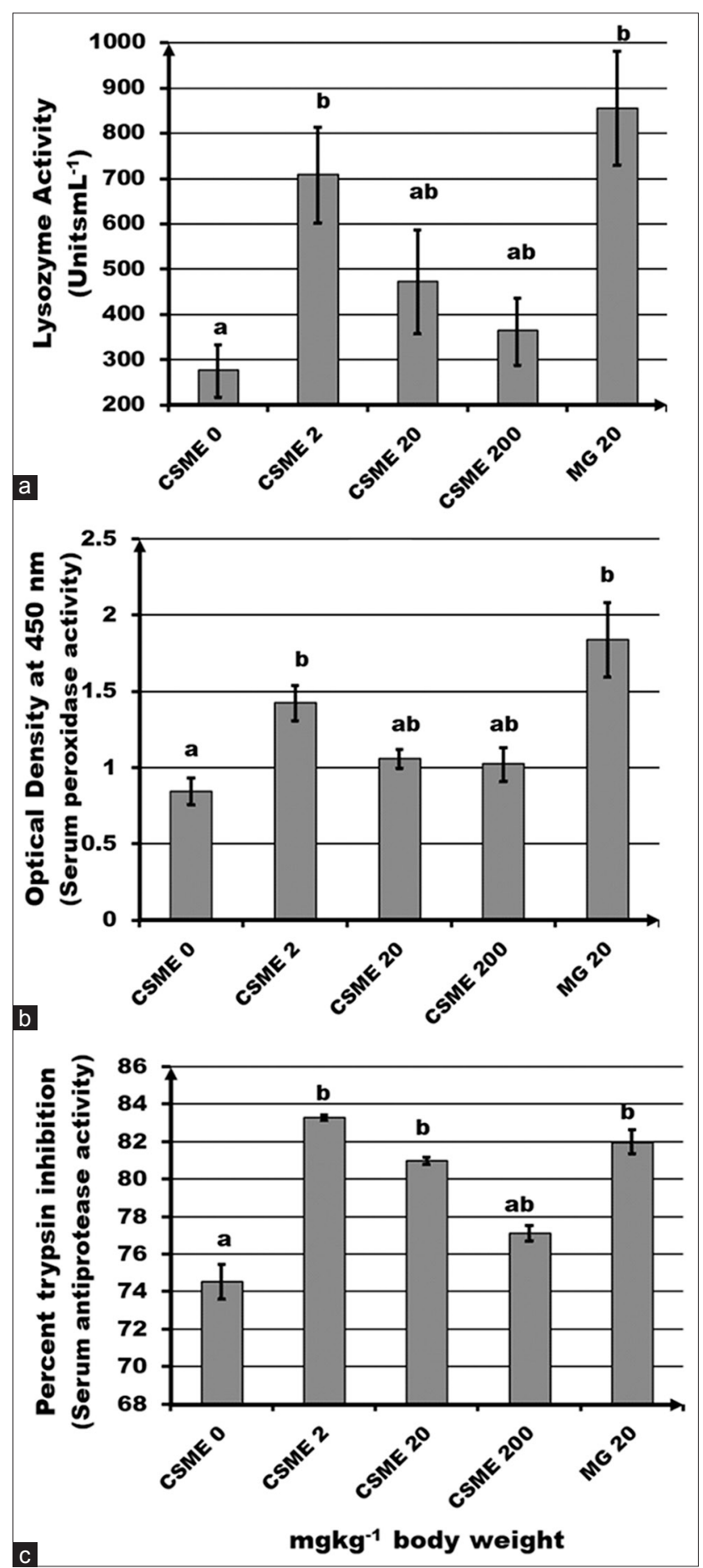

Figure-1: Effect of intraperitoneal administration (mg/ $\mathrm{kg}$ body weight) of Caulerpa scalpelliformis of methanolic extract on (a) serum lysozyme, (b) serum myeloperoxidase, and (c) serum antiprotease activities. Each point represents mean \pm standard error of 12 fish. Different alphabets represent significant difference $(p<0.05)$ between means as assessed by one-way ANOVA with Tukey's a posteriori test.

aquaculture. Plant-derived immunostimulants have been found to improve the non-specific immunity in fish by enhancing the immune mechanisms such as lysozyme, myeloperoxidase, and expression of immune genes $[23,24]$. The current study explores the potential of CSME in boosting the non-specific immunity in $O$. niloticus with the subsequent protection from 
A. hydrophila infection. The quaternary alkaloids and polysaccharides fractions from the same macroalga had been reported earlier to be immunostimulating in the striped murrel, Channa striata, and O. niloticus, respectively $[14,25]$.

Lysozyme is considered as a crucial bactericidal enzyme of the innate immunity [26]. Mice lacking lysozyme showed a decline in the removal of Pseudomonas aeruginosa from the airways [27]. In the present study,

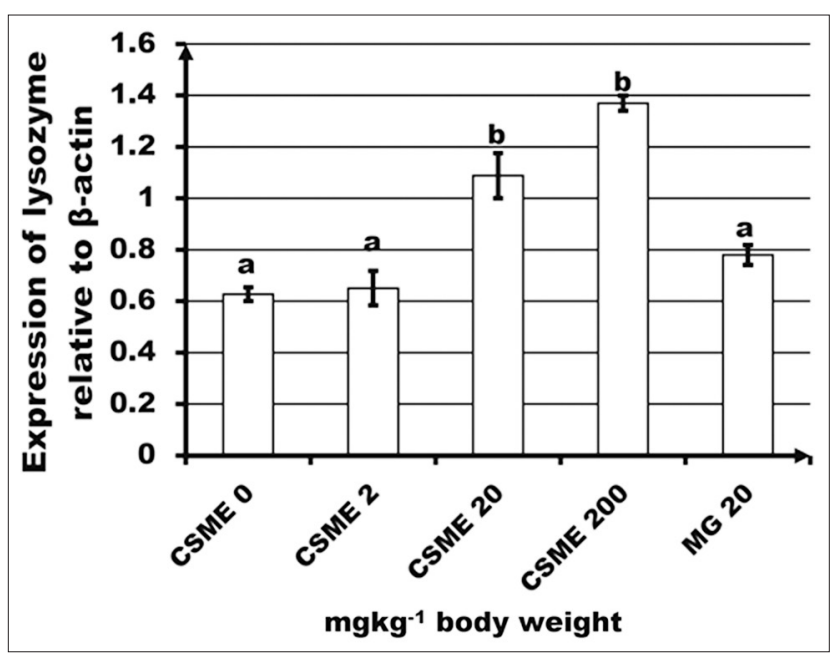

Figure-2: Effect of Caulerpa scalpelliformis methanolic extract on lysozyme expression in the spleen of Oreochromis niloticus. Each point represents mean \pm standard error of 3 fish. Different alphabets represent a significant difference $(p<0.05)$ between means as assessed by one-way ANOVA with Tukey's a posteriori test. treatment with a low dose of CSME to O. niloticus resulted in augmentation of the lysozyme activity when compared with that of the untreated control. In comparable studies conducted elsewhere, Mozambique tilapia fed with a diet enriched with ethanolic extract of bee glue, Propolis, showed an increase in the serum lysozyme activity [23]. Polysaccharide from the brown alga Padina gymnospora also boosted the serum lysozyme activity in carps [28]. Increased lysozyme activity protects fishes from various pathogens and confers a higher degree of disease resistance [29]. In the present investigation, the mid and high doses of CSME increased the expression of gene encoding lysozyme. Recently in the same fish species, the plant-derived traditional Chinese medicine preparation has been shown to enhance the expression of lysozyme gene [30].

Myeloperoxidase produced in the neutrophils catalyzes the formation of hypochlorous acid from hydrogen peroxide which is lethal to living cells [31]. Infection with Candida albicans in myeloperoxidase lacking zebrafish led to a failure in the removal of the pathogen [32]. In the present study, the low dose resulted in an increase in myeloperoxidase activity. Supplementation of Ecklonia cava, a brown alga to the diet of olive flounder, increased the myeloperoxidase activity [33]. In another similar study, the diet of kelp grouper, Epinephelus bruneus, was enriched with ethanol extract of Siegesbeckia glabrescens that augmented the production of myeloperoxidase [34].

Antiprotease acting against the proteolytic enzymes secreted by pathogens also has a role in acute
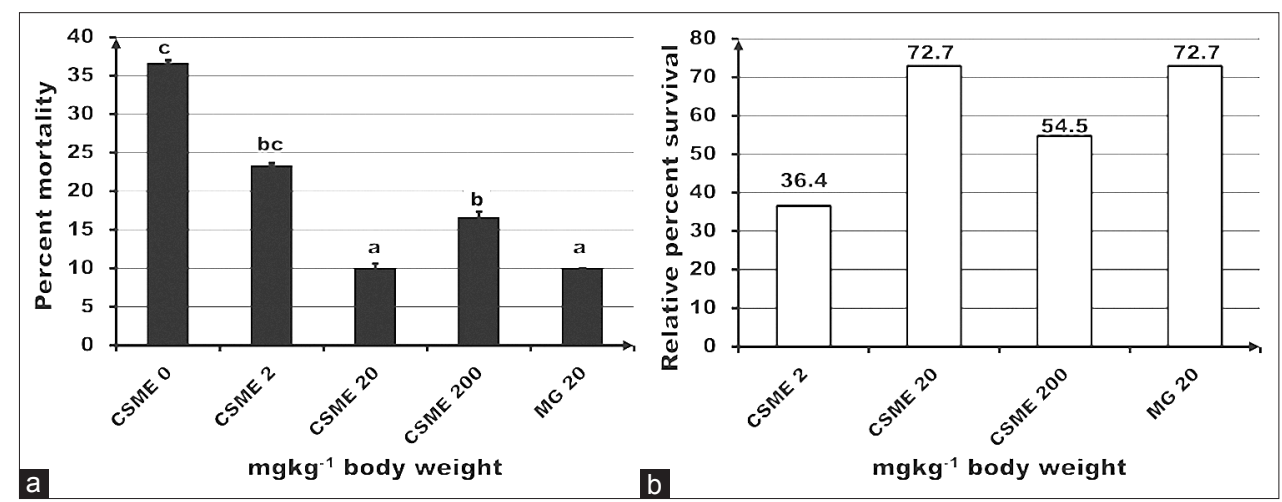

Figure-3: Effect of Caulerpa scalpelliformis methanolic extract on disease resistance in terms of (a) percent mortality to Aeromonas hydrophila and (b) relative percent survival. Each point represents mean \pm standard error of 30 fish. Different alphabets represent a significant difference $(p<0.05)$ between means as assessed by one-way ANOVA with Tukey's a posteriori test.

Table-1: Details of primer sequences used in this study.

\begin{tabular}{|c|c|c|c|c|c|}
\hline S.No. & $\begin{array}{l}\text { Name of } \\
\text { the gene }\end{array}$ & $\begin{array}{l}\text { Annealing } \\
\text { temperature }\end{array}$ & Primer sequences $3^{\prime} \rightarrow 5^{\prime}$ & $\begin{array}{l}\text { PCR product } \\
\text { size }\end{array}$ & References \\
\hline 1. & $\beta$-actin & $60^{\circ} \mathrm{C}$ & $\begin{array}{l}\text { F: CCACACAGTGCCCATCTACGA } \\
\text { R: CCACGCTCTGTCAGGATCTTCA }\end{array}$ & 100-110bp & {$[20]$} \\
\hline 2. & TNF- $\alpha$ & $55^{\circ} \mathrm{C}$ & $\begin{array}{l}\text { F: CCTGGCTGTAGACGAAGT } \\
\text { R: TAGAAGGCAGCGACTCAA }\end{array}$ & $134 b p$ & {$[21]$} \\
\hline 3. & Lysozyme & $60^{\circ} \mathrm{C}$ & $\begin{array}{l}\text { F: TTGGGAGTGTTCAACAGTGG } \\
\text { R: GCCTCTGACAGCATTTGACA }\end{array}$ & $300 b p$ & $\begin{array}{c}\text { Self-designed } \\
\text { (http://primer3.ut.ee/) }\end{array}$ \\
\hline
\end{tabular}

$\mathrm{PCR}=$ Polymerase chain reaction 
phase reactions [35]. In the present study, a significant boost in antiprotease activity was noticeable by the action of low and mid doses. This is in agreement with another finding in this laboratory wherein intraperitoneal administration of methanolic extract of night jasmine seeds in tilapia increased the serum antiprotease activity [36]. Sophora flavescens as a dietary supplement in tilapia also led to an increase in the antiprotease activity [37].

Challenging fish with an LD of the microbe and checking its survival can be used as a "golden standard" to determine the potential of an immunostimulant [38]. Here, in this study, the mid and high doses conferred very good protection in fish against A. hydrophila when compared to the untreated control. African catfish fed with diet supplemented with ethanolic extract of Ocimum gratissimum maximized protection from Listeria monocytogenes [39]. Survival in tilapia against Streptococcus agalactiae was increased when fed for 20 days with a diet supplemented with aqueous extract of Cratoxylum formosum [40]. Methanolic extract of Punica granatum leaves enhanced resistance in olive flounder from lymphocystis disease virus [41].

\section{Conclusion}

Intraperitoneal administration of CSME stimulated the non-specific immune responses of $O$. niloticus. CSME protected O. niloticus when infected experimentally with $A$. hydrophila. Hence, CSME used in the study has the potential of being a candidate for immunostimulant in finfish aquaculture. However, field trials will be a prerequisite before any application attempt in large-scale farms.

\section{Authors' Contributions}

The results reported herewith are part of OY's doctoral thesis. RDM designed the work. OY and KSS did the experiments and collected the results. PAS and RDM compiled the results and drafted the manuscript. All authors read and approved the final manuscript.

\section{Acknowledgments}

The financial support for the study provided by the Department of Biotechnology, Government of India, New Delhi (grant sanction no. BT/PR7726/ $\mathrm{AAQ} / 3 / 634 / 2013$ ) is gratefully acknowledged.

\section{Competing Interests} interests.

The authors declare that they have no competing

\section{Publisher's Note}

Veterinary World remains neutral with regard to jurisdictional claims in published institutional affiliation.

\section{References}

1. Food and Agriculture Organization. (2016) The State of World Fisheries and Aquaculture 2016. Food and
Agriculture Organization, Rome. p200.

2. Subramani, P.A. and Michael, R.D. In: Jeney, G., editor. (2017) Prophylactic and Prevention Methods Against Diseases in Aquaculture, in Fish Diseases. Academic Press, Cambridge, Massachusetts, United States. p81.

3. Awad, E. and Awaad, A. (2017) Role of medicinal plants on growth performance and immune status in fish. Fish Shellfish Immunol., 67: 40-54.

4. Charoonnart, P., Purton, S. and Saksmerprome, V. (2018) Applications of microalgal biotechnology for disease control in aquaculture. Biology (Basel), 7(2): e24.

5. Øverland, M., Mydland, L.T. and Skrede, A. (2018) Marine macroalgae as sources of protein and bioactive compounds in feed for monogastric animals. J. Sci. Food Agric., 99(1): 13-24.

6. Sharma, B.R. and Rhyu, D.Y. (2014) Anti-diabetic effects of Caulerpa lentillifera: Stimulation of insulin secretion in pancreatic $\beta$-cells and enhancement of glucose uptake in adipocytes. Asian Pac. J. Trop. Biomed., 4(7): 575-580.

7. da Matta, C.B.B., de Souza, É.T., de Queiroz, A.C., de Lira, D.P., de Araújo, M.V., Cavalcante-Silva, L.H.A., de Miranda, G.E.C., deAraújo-Júnior,J.X., Barbosa-Filho,J.M., de Oliveira Santos, B.V. and Alexandre-Moreira, M.S. (2011) Antinociceptive and anti-inflammatory activity from algae of the genus Caulerpa. Mar. Drugs, 9(3): 307-318.

8. Chia, Y.Y., Kanthimathi, M.S., Khoo, K.S., Rajarajeswaran, J., Cheng, H.M. and Yap, W.S. (2015) Antioxidant and cytotoxic activities of three species of tropical seaweeds. $B M C$ Complement. Altern. Med., 15(1): 339.

9. Klein, J. and Verlaque, M. (2008) The Caulerpa racemosa invasion: A critical review. Mar. Pollut. Bull., 56(2): 205-225.

10. Khaw, H.L., Ponzoni, R.W. and Danting, M.J.C. (2008) Estimation of genetic change in the GIFT strain of nile tilapia (Oreochromis niloticus) by comparing contemporary progeny produced by males born in 1991 or in 2003 . Aquaculture, 275(1): 64-69.

11. Rakocy, J.E. (2005) Cultured Aquatic Species Information Programme. Oreochromis niloticus, 2005. FAO Fisheries and Aquaculture Department, Rome.

12. Zhang, D., Xu, D.H. and Shoemaker, C. (2016) Experimental induction of motile Aeromonas septicemia in channel catfish (Ictalurus punctatus) by waterborne challenge with virulent Aeromonas hydrophila. Aquaculture Rep., 3(1): $18-23$.

13. Jenkins, J.A., Bart, H.L.Jr., Bowker, J.D., Bowser, P.R., MacMillan, J.R., Nickum, J.G., Rachlin, J.W., Rose, J.D., Sorensen, P.W., Warkentine, B.E. and Whitledge, G.W. (2014) Guidelines for the use of fishes in research: Revised and expanded. Fisheries, 39(9): 415-416.

14. Yengkhom, O., Shalini, K.S., Subramani, P.A. and Michael, R.D. (2018) Non-specific immunity and disease resistance are enhanced by the polysaccharide fraction of a marine chlorophycean macroalga in Oreochromis niloticus (Linnaeus, 1758). J. Appl. Ichthyol., 34(3): 556-567.

15. Das, S., Das, K. and Dubey, V. (2011) Inhibitory activity and phytochemical assessment of ethno-medicinal plants against some human pathogenic bacteria. J. Med. Plant. Res., 5(29): 6536-6543.

16. Michael, R.D., Srinivas, S.D, Sailendri K. and Muthukkaruppan, V.R. (1994) A rapid method for repetitive bleeding in fish. Indian J. Exp. Biol., 32(11): 838.

17. Hutchinson, T.H. and Manning, M.J. (1996) Seasonal trends in serum lysozyme activity and total protein concentration in dab (Limanda limanda L.) sampled from Lyme Bay, U.K. Fish Shellfish Immunol., 6(7): 473.

18. Quade, M.J. and Roth, J.A. (1997) A rapid, direct assay to measure degranulation of bovine neutrophil primary granules. Vet. Immunol. Immunopathol., 58(3-4): 239-248.

19. Bowden, T.J., Butler, R., Bricknell, I.R. and Ellis, A.E. (1997) Serum trypsin-inhibitory activity in five species of farmed fish. Fish Shellfish Immunol., 7(6): 377. 
20. Qiang, J., He, J., Yang, H., Wang, H., Kpundeh, M.D., Xu, P. and Zhu, Z.X. (2014) Temperature modulates hepatic carbohydrate metabolic enzyme activity and gene expression in juvenile GIFT tilapia (Oreochromis niloticus) fed a carbohydrate-enriched diet. J. Therm. Biol., 40: 25-31.

21. Tang, J., Cai, J., Liu, R., Wang, J., Lu, Y., Wu, Z. and X (2014) Immunostimulatory effects of artificial feed supplemented with a Chinese herbal mixture on Oreochromis niloticus against Aeromonas hydrophila. Fish Shellfish Immunol., 39(2): 401.

22. Schneider, C.A., Rasband, W.S. and Eliceiri, K.W. (2012) NIH Image to Image: 25 years of image analysis. Nat. Methods, 9(7): 671.

23. Baba, E., Acar, Ü., Yılmaz, S., Zemheri, F. and Ergün, S. (2018) Dietary olive leaf (Olea europea L.) extract alters some immune gene expression levels and disease resistance to Yersinia ruckeri infection in rainbow trout Oncorhynchus mykiss. Fish Shellfish Immunol., 79: 28-33.

24. Acar, Ü. (2018) Effects of diet supplemented with ethanolic extract of propolis on growth performance, hematological and serum biochemical parameters and disease resistance of Mozambique tilapia (Oreochromis mossambicus) against Streptococcus iniae. Aquaculture, 495: 339-344.

25. Balasubramanian, R. and Michael, R.D. (2016) Immunostimulatory effects of N-oxide Quaternary alkaloid fraction of a marine Chlorophycean macroalga in the striped murrel, Channa striata (Bloch). Aquaculture Res., 47(2): 591-604.

26. Luo, C., Gwekwe, B., Choto, P., Miao, W., Chen, M., Xue, C., Xu, Y., Yin, X., Magawa, G., Wu, D., Akida, J.S., Wang, L., Li, Q. and Deng, S. (2018) Bitter peptides from enzymatically hydrolyzed protein increase the number of leucocytes and lysozyme activity of large yellow croaker (Larimichthys crocea). Fish Shellfish Immunol., 81: 130-134.

27. Cole, A.M., Thapa, D.R., Gabayan, V., Liao, H.I., Liu, L. and Ganz, T. (2005) Decreased clearance of Pseudomonas aeruginosa from airways of mice deficient in lysozyme M. J. Leukoc. Biol., 78(5): 1081-1085.

28. Rajendran, P., Subramani, P.A. and Michael, D. (2016) Polysaccharides from marine macroalga, Padina gymnospora improve the nonspecific and specific immune responses of Cyprinus carpio and protect it from different pathogens. Fish Shellfish Immunol., 58: 220-228.

29. Fletcher, G.L., Hobbs, R.S., Evans, R.P., Shears, M.A., Hahn, A.L. and Hew, C.L. (2011) Lysozyme transgenic Atlantic salmon (Salmo salar L.). Aquaculture Res., 42(3): 427-440.

30. Abarike, E.D., Jian, J., Tang, J., Cai, J., Yu, H., Lihua, C. and Jun, L. (2018) Influence of traditional Chinese medicine and Bacillus species (TCMBS) on growth, immune response and disease resistance in Nile tilapia, Oreochromis niloticus. Aquaculture Res., 49(7): 2366-2375.

31. Yeh, H.Y. and Klesius, P.H. (2013) Changes of serum myeloperoxidase and nitric oxide in the early stage of Edwardsiella ictaluri infection in channel catfish, Ictalurus punctatus (Rafinesque). J. Fish Dis., 36(4): 441-446.

32. Wang, K., Fang, X., Ma, N., Lin, Q., Huang, Z., Liu, W., Xu, M., Chen, X., Zhang, W. and Zhang, Y. (2015) Myeloperoxidase-deficient zebrafish show an augmented inflammatory response to challenge with Candida albicans. Fish Shellfish Immunol., 44(1): 109-116.

33. Kim, S.S. and Lee, K.J. (2008) Effects of dietary kelp (Ecklonia cava) on growth and innate immunity in juvenile olive flounder Paralichthys olivaceus (Temminck et Schlegel). Aquaculture Res., 39(15): 1687-1690.

34. Harikrishnan, R., Kim, D.H., Hong, S.H., Mariappan, P., Balasundaram, C. andHeo,M.S.(2012)Non-specificimmune response and disease resistance induced by Sigesbeckia glabrescens against Vibrio parahaemolyticus in Epinephelus bruneus. Fish Shellfish Immunol., 33(2): 359-364.

35. Magnadóttir, B. (2006) Innate immunity of fish (overview). Fish Shellfish Immunol., 20(2): 137-151.

36. Kirubakaran, C.J.W., Subramani, P.A. and Michael, R.D. (2016) Methanol extract of Nyctanthes arbor-tristis seeds enhances non-specific immune responses and protects Oreochromis mossambicus (Peters) against Aeromonas hydrophila infection. Res. Vet. Sci., 105: 243-248.

37. Wu, Y.R., Gong, Q.F., Fang, H., Liang, W.W., Chen, M. and He, R.J. (2013) Effect of Sophora flavescens on non-specific immune response of tilapia (GIFT Oreochromis niloticus) and disease resistance against Streptococcus agalactiae. Fish Shellfish Immunol., 34(1): 220-227.

38. Boshra, H., Li, J. and Sunyer, J.O. (2006) Recent advances on the complement system of teleost fish. Fish Shellfish Immunol., 20(2): 239-262.

39. Abdel-Tawwab, M., Adeshina, I., Jenyo-Oni, A., Ajani, E.K. and Emikpe, B.O. (2018) Growth, physiological, antioxidants, and immune response of African catfish, Clarias gariepinus (B.), to dietary clove basil, Ocimum gratissimum, leaf extract and its susceptibility to Listeria monocytogenes infection. Fish Shellfish Immunol., 78: 346-354.

40. Rattanachaikunsopon, P. and Phumkhachorn, P. (2010) Effect of Cratoxylum formosum on innate immune response and disease resistance against Streptococcus agalactiae in tilapia Oreochromis niloticus. Fish. Sci., 76(4): 653-659.

41. Harikrishnan, R., Heo, J., Balasundaram, C., Kim, M.C., Kim, J.S., Han, Y.J. and Heo, M.S. (2010) Effect of Punica granatum solvent extracts on immune system and disease resistance in Paralichthys olivaceus against lymphocystis disease virus (LDV). Fish Shellfish Immunol., 29(4): 668-673. 